\title{
IMPACT OF GROUNDWATER SALINITY ON AGRICULTURAL PRODUCTIVITY WITH CLIMATE CHANGE IMPLICATIONS
}

\author{
MUTASEM EL-FADEL ${ }^{1}$, TANYA DEEB ${ }^{1}$, IBRAHIM ALAMEDDINE ${ }^{1}$, \\ RAMI ZURAYK ${ }^{2} \& \mathrm{JAD} \mathrm{CHAABAN}^{2}$ \\ ${ }^{1}$ Department of Civil \& Environmental Engineering, Faculty of Engineering \& Architecture, \\ American University of Beirut, Beirut, Lebanon. \\ ${ }^{2}$ Department of Landscape and Ecosystem Management, Faculty of Agriculture and Food Sciences, \\ American University of Beirut, Beirut, Lebanon.
}

\begin{abstract}
This study examines the impacts of increased salinity on agricultural productivity and groundwater use for irrigation with the aim to cope with overexploitation associated with potential climate change impacts. For this purpose, a farmers' field survey was conducted at a pilot plain with banana plantations partially irrigated with saline groundwater. The economic burden of increased salinity was examined using a crop-water production function relating water salinity and yield with production cost and selling prices. Current production rates in low salinity plots were greater than those in high salinity plots by an average of $25 \%$, representing the salinity burden incurred by farmers. We close with highlighting mitigation measures and adaptation strategies under potential future climatic changes that are expected to exacerbate irrigation with high salinity groundwater.

Keywords: adaptation, agricultural yield, economic burden, Saltwater intrusion
\end{abstract}

\section{INTRODUCTION}

The vulnerability of coastal groundwater resources to saltwater intrusion has evolved to become a challenge of global proportions with the Mediterranean and South-Atlantic coastal aquifers being highly affected [1]. The situation is more critical in arid and semi-arid climatic regions such as the Eastern Mediterranean, where freshwater resources are limited in comparison with continuously increasing water demand [2,3]. Overexploitation and mismanagement increased the potential of saltwater intrusion, which can negatively affect agricultural yield of coastal crops and plantations through the accumulation of salts causing adverse effects on soils and plants.

Soil salinity reduces water infiltration rates reflected by the breakdown of soil aggregates and the dispersion and swelling of clay minerals that result in poor crop establishment. Moreover, groundwater salinization increases the presence of salts in the root zone, which exerts an osmotic effect on plants forcing them to spend more energy to extract water from the soil and hence consuming this energy instead of using it for growth, flowering or fruiting and thus, the plant's ability to grow is stunted [4]. Increased salinity also reduces plant growth and yield through ion toxicity, defined by an accumulation of $\mathrm{Na}^{+}$and $\mathrm{Cl}^{-}$ions $[5,6]$, which employ competitive interactions with other nutrient ions (e.g. $\mathrm{K}^{+}, \mathrm{NO}_{3}^{-}, \mathrm{H}_{2} \mathrm{PO}_{4}^{-}$) for binding sites and transport proteins in root cells causing nutrient imbalance in plants. Ion toxicity affects crop production directly as diminished nutritional relations $\left(\mathrm{Ca}^{2+} / \mathrm{Na}^{+}\right.$and $\left.\mathrm{K}^{+} / \mathrm{Na}^{+}\right)$ decrease the crop's economic and nutritional value due to reduced fruit size and shelf life, non-uniform fruit shape, and decreased vitamin content [7].

The physiological impacts of salinity on soils and crops/plants, the loss in crop/plant yield and the decreased quality of crops/plants reduce the economic attractiveness of salt-sensitive coastal crops [8-10] that have low tolerance for salts. In this context, this study attempts to assess the impacts of saltwater intrusion on agricultural productivity with associated 
economic implications highlighting mitigation measures and adaptation strategies under potential future climatic changes.

\section{METHODS}

A farmers' field survey, economic assessment, and development of a mitigation / adaptation framework were conducted at a coastal agricultural area along the Eastern Mediterranean in Lebanon (Fig. 1). The pilot area, which relies partially on groundwater resources for crop / plant irrigation, was selected based on field screening surveys involving multiple site visits, interviews with key informants, and water quality data ascertaining the occurrence of saltwater intrusion due to groundwater overexploitation and potential climate change impacts [8]. The main plantation grown in the area consists of banana, which is salt-sensitive and susceptible to the effects of irrigation with saline water [12-14].

\subsection{Farmers' Field Survey}

The impacts of saltwater intrusion on agricultural production and crop yield were assessed using a field survey questionnaire administered to farmers through a one on one interview process to collect information related to (a) wells (number per plot, elevation and depth, frequency of use, water quality perception), (b) banana production yield and selling prices, (c) irrigation (methods used, frequency, sources, expenditure) and (d) fertilizer (type, quantity, expenditure).

\subsection{Economic Assessment}

The adverse effect of groundwater salinity on crop yield is translated into an economic burden on farmers, which can be assessed using a crop-water production function that relates water salinity and crop yield coupled with the production cost and selling prices of banana obtained
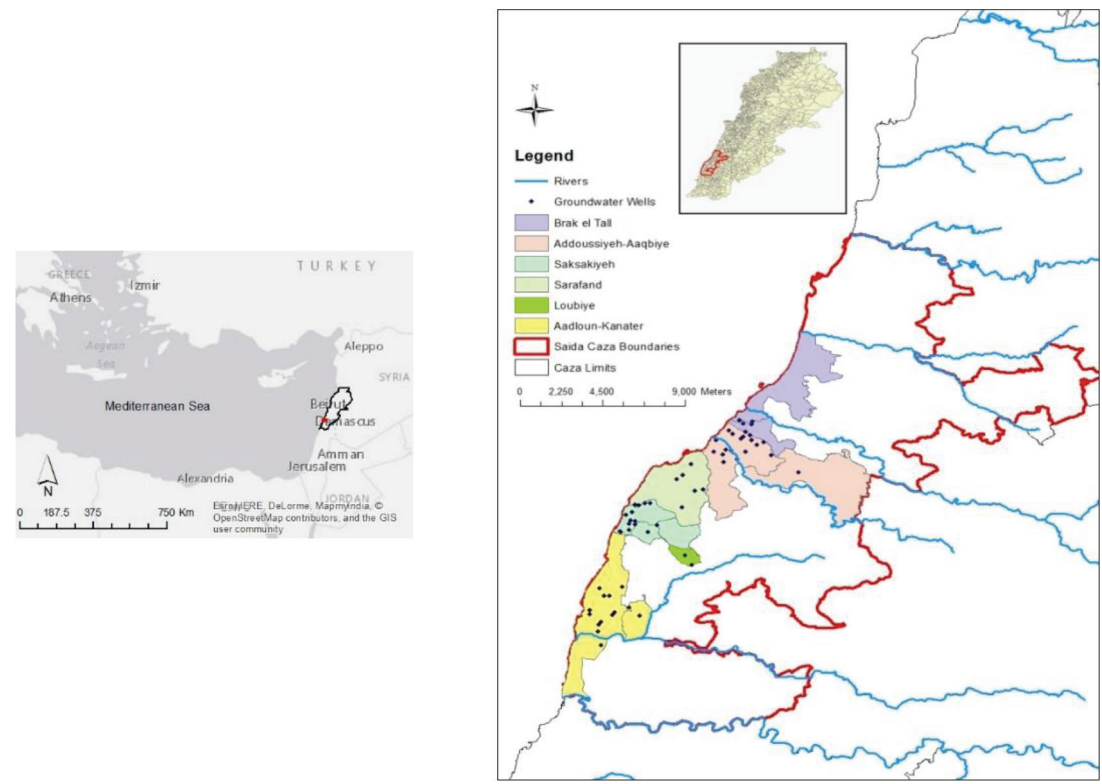

Figure 1: Pilot study area with location of irrigation wells. 
through the farmers' questionnaires as expressed in equation (1). Two salinity groups were established based on farmers irrigating with water at $\mathrm{EC}_{\mathrm{w}}<1 \mathrm{dS} / \mathrm{m}$ (low salinity group) and farmers irrigating with water at $\mathrm{EC}_{\mathrm{w}}>1 \mathrm{dS} / \mathrm{m}$ (high salinity group).

$$
\mathrm{N}_{\mathrm{r}}=\mathrm{T}_{\mathrm{r}}-\mathrm{P}_{\mathrm{c}} ; \mathrm{T}_{\mathrm{r}}=\mathrm{Y}_{\mathrm{b}} \mathrm{xS} ; \mathrm{P}_{\mathrm{c}}=\mathrm{L}_{\mathrm{c}}+\mathrm{GW}_{\mathrm{c}}+\mathrm{SW}_{\mathrm{c}}+\mathrm{F}_{\mathrm{c}}+\mathrm{I}_{\mathrm{c}}
$$

where $\mathrm{N}_{\mathrm{r}}=$ Net revenue $\left(\$ / \mathrm{m}^{2} / \mathrm{yr}\right) ; \mathrm{T}_{\mathrm{r}}=$ Total revenue $\left(\$ / \mathrm{m}^{2} / \mathrm{yr}\right) ; \mathrm{P}_{\mathrm{c}}=$ Production cost $\left(\$ / \mathrm{m}^{2} /\right.$ $\mathrm{yr}) ; \mathrm{Y}_{\mathrm{b}}=$ Banana yield $\left(\mathrm{kg} / \mathrm{m}^{2} / \mathrm{yr}\right) ; \mathrm{S}_{\mathrm{p}}=$ Selling price of banana $(\$ / \mathrm{kg}) ; \mathrm{L}_{\mathrm{c}}=$ Labor cost $\left(\$ / \mathrm{m}^{2} /\right.$ $\mathrm{yr}) ; \mathrm{GW}_{\mathrm{c}}=$ Groundwater extraction cost $\left(\$ / \mathrm{m}^{2} / \mathrm{yr}\right)$ (diesel, electricity \& maintenance); $\mathrm{SW}_{\mathrm{c}}$ $=$ Surface water cost $\left(\$ / \mathrm{m}^{2} / \mathrm{yr}\right)$ (subscription tariff); $\mathrm{F}_{\mathrm{c}}=$ Fertilizer cost $\left(\$ / \mathrm{m}^{2} / \mathrm{yr}\right)$ (mineral and organic); $I_{c}=$ Irrigation cost $\left(\$ / \mathrm{m}^{2} / \mathrm{yr}\right)$ (drip and sprinkler systems).

Additionally, the Ayers \& Westcot [15] model (eqn 2) that links banana yields to soil salinity $\left(\mathrm{EC}_{\mathrm{s}}\right)$ was used whereby $\mathrm{EC}_{\mathrm{s}}$ values were calculated from measured groundwater salinity $\left(\mathrm{EC}_{\mathrm{w}}\right)$ levels as expressed in equation (2a). The model predicts that the maximum banana yield happens when $\mathrm{EC}_{\mathrm{w}}$ is $<1 \mathrm{dS} / \mathrm{m}$ ) with values $>1 \mathrm{dS} / \mathrm{m}$ inducing production losses reaching a $100 \%$ decrease when $\mathrm{EC}_{\mathrm{w}}$ exceeds $6.4 \mathrm{dS} / \mathrm{m}$ (Table 1 ).

$$
\mathrm{Y}=100-\mathrm{b}\left(\mathrm{EC}_{\mathrm{s}}-\mathrm{a}\right) ; \mathrm{EC}_{\mathrm{s}}=1.5 \times \mathrm{EC}_{\mathrm{w}},
$$

where $\mathrm{Y}=$ Banana yield $(\%) ; \mathrm{a}=$ Salinity threshold value $(\mathrm{ds} / \mathrm{m})=0.73$ for banana $[16]$; and $\mathrm{b}=$ Yield loss per unit increase in soil salinity $(\%)=27.8 \%$ for banana [16]

\subsection{Mitigation and Adaptation Framework}

A framework for mitigation measures and adaptation strategies was developed in an effort to minimize saltwater intrusion and/or cope with increased salinity particularly in the context of future climate change impacts when salinities are expected to increase. The framework discusses the institutions responsible within the water sector, as pertaining to groundwater management and protection. Local and wider-scale measures are outlined with technical, financial and administrative constraints. Adaptation strategies and common irrigation management practices pertaining to agricultural productivity are equally presented under potential future climatic changes.

\section{RESULTS AND DISCUSSIONS}

\subsection{Farmers' Field Survey}

A total of 39 questionnaires were administered through the one-on-one interview process with farmers. The land plots in the study area varied in size with an average of $\sim 100,000 \mathrm{~m}^{2}$

Table 1: Salinity impact of banana yield.

\begin{tabular}{lll}
\hline $\begin{array}{l}\text { Potential Yield } \\
(\%)\end{array}$ & $\begin{array}{l}\mathrm{EC}_{\mathrm{s}} \\
(\mathrm{dS} / \mathrm{m})\end{array}$ & $\begin{array}{l}\mathrm{EC}_{\mathrm{w}} \\
(\mathrm{dS} / \mathrm{m})\end{array}$ \\
\hline 100 & 0.7 & 1.0 \\
90 & 1.1 & 1.6 \\
75 & 1.6 & 2.4 \\
50 & 2.5 & 3.8 \\
0 & 4.3 & 6.4 \\
\hline
\end{tabular}


Table 2: Descriptive statistics for plot properties.

\begin{tabular}{llll}
\hline Property & Minimum & Maximum & Average \\
\hline Total plot size $\left(\mathrm{m}^{2}\right)$ & 1,300 & $1,000,000$ & 100,000 \\
Total area of banana grown $\left(\mathrm{m}^{2}\right)$ & 250 & 350,000 & 40,030 \\
Number of wells per plot & 1 & 6 & 1.7 \\
Well elevation (m, above sea level) & 1.3 & 171.6 & 37.1 \\
Well depth $(\mathrm{m})$ & 6 & 450 & 123.3 \\
\hline
\end{tabular}

(Table 2). Each plot had at least one well (54.7\%), with $45.3 \%$ having two or more wells. The wells were located at an elevation ranging between 1.3 and $171.6 \mathrm{~m}$ above sea level, averaging at $\sim 37 \mathrm{~m}$. Well depths ranged from $6 \mathrm{~m}$ to $450 \mathrm{~m}$ with an average of $123 \mathrm{~m}$. While the main source of irrigation for banana is groundwater from wells located at the plots $(53.8 \%$ of famers), more than $42 \%$ of farmers used a regional irrigation project in conjunction with well water for irrigation purposes and only $1.9 \%$ relied exclusively on surface water. Average irrigation time was around 4 hours a day with the surface water received through the regional irrigation project being heavily subsidized at a tariff based on the size of the cultivated land (average of $0.03 \mathrm{USD} / \mathrm{m}^{2} /$ year) instead of actual volume used [17,18], which encourages water wastage with less commitment to conservation measures. While no tariff imposed on groundwater with most wells being unlicensed/unregulated, farmers still incur expenses associated with water extraction (pump maintenance and electricity or fuel for operating private generators). Combining the costs pertaining to pump maintenance, electricity and diesel fuel costs, the average cost of providing water from wells over the irrigation season (starting in May and ending with the first rain of the fall-winter season) reaches $\sim 0.38$ USD/ $\mathrm{m}^{2} /$ year, nearly 13 folds of the governmental surface water tariff.

Banana production in the region is a dominant trade with a strong year-round season and a variety of bananas grown. According to the field survey interviews, $51 \%$ of bananas grown are of the Dwarf Cavendish (DC) group with $27.5 \%$ of farmers growing both DC and Giant Cavendish (GC) groups simultaneously. The average land size that is grown with banana in the pilot area was around $40,000 \mathrm{~m}^{2}$, with an average production yield of $7 \mathrm{~kg} / \mathrm{m}^{2}$. The trade season begins in October for a high cost of $1.2 \mathrm{USD} / \mathrm{kg}$ that drops by April to reach a low of $0.3 \mathrm{USD} / \mathrm{kg}$ because of high production.

\subsection{Economic Implications}

When revenue was compared across the two salinity groups, the low salinity group $(\mathrm{n}=21$; $\left.\mathrm{EC}_{\mathrm{w}}<1 \mathrm{dS} / \mathrm{m}\right)$ had a greater revenue than the high salinity group $\left(\mathrm{n}=18 ; \mathrm{EC}_{\mathrm{w}}>1 \mathrm{dS} / \mathrm{m}\right)$, by $\sim 2.5 \mathrm{USD} / \mathrm{m}^{2} /$ year, representing the monetary burden incurred by farmers due to increased salinity. Soil conditions and the physiological nature of banana are factors that could potentially influence the effect of salinity on its production. Moreover, the use of fresh surface water from the regional irrigation project in conjunction with well water is also expected to reduce the effects of saline groundwater on yields and revenues. As salinity levels continue to rise, their impact on banana production will become more pronounced.

The maximum yield in the study area was set at $\sim 7.4 \mathrm{~kg} / \mathrm{m}^{2}$, which is the average yield reported by farmers cultivating under optimal conditions for banana growth (i.e. yield of 
farmers with $\mathrm{EC}_{\mathrm{w}}$ less than $1 \mathrm{dS} / \mathrm{m}$ ). Overall, the maximum crop yield in the pilot area is close to the national yield that averages $8 \mathrm{~kg} / \mathrm{m}^{2}$ [16]. On the other hand, the yield at farms with $\mathrm{EC}_{\mathrm{w}}$ exceeding $1 \mathrm{dS} / \mathrm{m}$ was around $5.6 \mathrm{~kg} / \mathrm{m}^{2}$. This signifies a yield decrease of approximately $25 \%$ at a corresponding $\mathrm{EC}_{\mathrm{w}}$ of about $2.4 \mathrm{dS} / \mathrm{m}$ (Table 1 ). In comparison to surrounding coastal areas in the MENA region, the reported yields are considered above average when compared to yields reported in dryer surrounding climates such as Egypt $\left(3.9 \mathrm{~kg} / \mathrm{m}^{2}\right)$ [17], Oman $\left(2.3 \mathrm{~kg} / \mathrm{m}^{2}\right)$ [21] and Jordan $\left(1 \mathrm{~kg} / \mathrm{m}^{2}\right)$ [22]. Evidently, current yields will be significantly affected if salinity levels continue to rise. For instance, current $\mathrm{EC}_{\mathrm{w}}$ levels along the same coast less than $30 \mathrm{kms}$ to the North, exceeded $16 \mathrm{dS} / \mathrm{m}$ as a result of overexploitation and mismanagement of groundwater resources [11]. If such levels reach the pilot area, the plantation of bananas will be economically non-viable. Under such a scenario, farmers will have to switch towards more salt-tolerant crops as was the case in the Al-Batinah region of Oman, whereby banana crops were replaced by salt-tolerant tomato varieties, when $\mathrm{EC}_{\mathrm{s}}$ values ranged between 2.5 and $7.5 \mathrm{dS} / \mathrm{m}$ [9].

\subsection{Mitigation and Adaptation Framework}

Within the context of saltwater intrusion, effective mitigation measures to reduce induced effects of groundwater overexploitation are imperative alongside adaptation strategies that involve the recognition of potential climate change impacts that are already occurring and will continue into the future requiring pre-planning to protect ecosystems from potential negative impacts [23]. In fact, the vulnerability of water resources to climate change impacts has been at the forefront of global climate change research. These impacts are reflected in many regions including the study area by an increase in temperature and a decrease in precipitation leading to an overall increase in the net demand for water [24]. Groundwater resources along coastal zones are particularly vulnerable in this context because of decreased aquifer recharge (lower precipitation) and increased water demand (higher temperature), resulting in greater groundwater abstraction and saltwater intrusion [25], potentially exacerbated by sea level rise (SLR) also associated with climate change (Fig. 2).

Naturally, the main apparent measure to control saltwater intrusion is the reduction of abstraction rates from irrigation wells, which can be achieved within an integrated framework under the governance of existing institutions towards protecting groundwater resources (Table 3). The framework encompasses physical control methods coupled with management activities, economic incentives and regulatory enforcement while considering constraints at various levels: technical, financial, as well administrative and institutional.

While mitigation measures have been at the forefront of various policy and management decisions, it has become increasingly evident that mitigation alone cannot be an effective strategy to limit the vulnerability to the causes and consequences of saltwater intrusion. Adaptation strategies, in synergy with mitigation measures, have become an inevitable part of the planning, policies and discussion procedures concerned with salinity management [26]. Such strategies encompass initiatives to reduce the susceptibility of natural and human systems against actual or expected climate change impacts [23]. In the context of adapting to saltwater intrusion, those may include relocating wells inland, changing land use patterns by switching to more salt-tolerant crops, and managing irrigation patterns to improve water use and enhance drainage and leaching of salts [27-29]. Within the study framework, the common agricultural practices that are followed in the pilot area include various on-farm irrigation management that improve crop-water relations, especially with respect to salinity management 


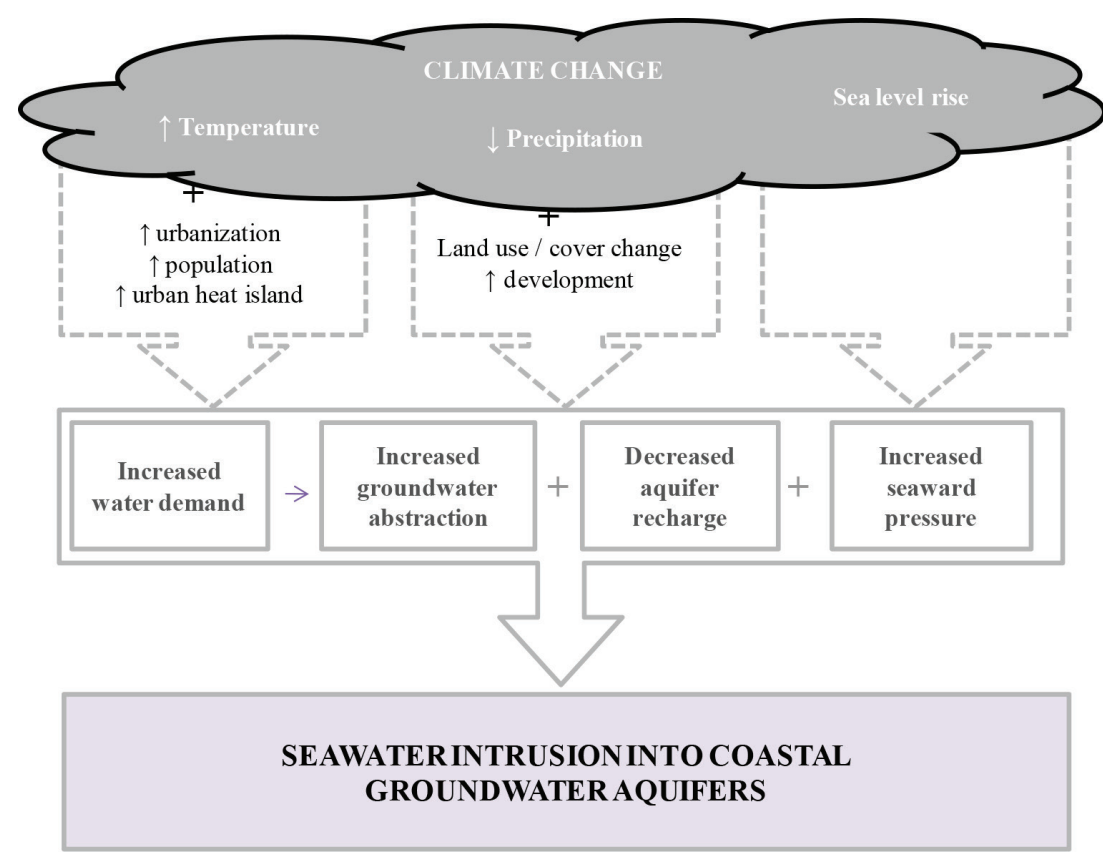

Figure 2: Dynamics of saltwater intrusion with potential climate change impacts.

such as the use of fertigation via drip irrigation, leaching of salts, and conjunctive use of groundwater and surface water. These practices are considered as adaptations measures that farmers tend to adopt independently to face aquifer salinization.

Fertigation via drip irrigation systems has proven to be an effective irrigation method to control salinity in soils by applying water precisely and uniformly at high frequencies, potentially increasing the yield and reducing root-zone soil salinity and drainage [38], thus providing improved disease management since only the soil is wetted whereas the leaf surface stays dry [39]. By supplying dissolved fertilizer to crops through an irrigation system, the nutrient-water relationship is more balanced to improve yield, save labor, and reduce compaction in the field resulting in the rapid and uniform uptake of nutrients by plants [40]. However, the initial installation cost for drip irrigation systems is high, with capital investment in the pilot area reaching $1.20 \mathrm{USD} / \mathrm{m}^{2} /$ year. Moreover, if poorly managed, salt accumulation may still occur between drip emitters, therefore it is advisable to design drip irrigation systems with closely spaced emitters and provide adequate leaching of salts. The latter is an effective method of adapting to increased soil salinity through excessive application of water to keep salts, which have accumulated in the soil, in soluble form and flush them below the crop root zone to maintain productivity [41]. Mostly, rainfall provides adequate leaching, as is the case in the pilot area. However, farmers tend to practice leaching via their scheduled irrigation patterns. For instance, in the pilot area, farmers have claimed to practice leaching every other time fertigation is performed, meaning that every time fertilizers are passed in the drip irrigation system, the next irrigation is without fertilizers, thus accumulated salts in the soil (from the irrigation water or from fertilizer residues) are flushed. Equally important is the conjunctive use of groundwater and surface water resources, which is considered a strategic approach to reduce the susceptibility of crops to salinity (Fig. 3). 
Table 3: Framework for controlling saltwater intrusion.

Common physical methods

\section{Subsurface barriers}

- Defined as underground semi-impervious or impervious structures constructed in coastal aquifers

- Simultaneously impedes inland infiltration of saltwater and increases groundwater storage capacity of an aquifer

Artificial recharge through injections wells

- Surface water is artificially made to infiltrate into the ground, commonly at rates and quantities greater than natural recharge

- Provides artificial recharge of confined aquifers and is effective in the case of highly fractured hard rocks and karstic limestone
Constraints [27, 30-33]

- High construction costs

- Procedural difficulties of political, social, and economic nature

- Problematic for arid and semi-arid regions with unavailability of adequate surface water in quantity and quality

- High capital, and operation and maintenance costs

- Efficacy is minimized for karstic highly fractured aquifers
Management activities

Regulating groundwater exploitation

- Reduction of pumping rates through tariff restructuring, metering water wells, and enforcing penalties for over-exploitation

Monitoring groundwater quality

- Establishing monitoring stations with regular testing for water quality parameters relevant to salinity

Regulating well permits and licensing

- Introduction of controls over the import of pumps and drilling equipment

\section{Rehabilitating/modernizing irrigation} systems

- Shifting from gravity-fed irrigation to pressurized systems using onfarm irrigation systems (e.g. drip irrigation)
Constraints [34-37]

Technical

- Insufficient number of skilled staff due to lack of up-to-date training and limited equipment for routine maintenance, measurement or monitoring of water supply and quality

- Lack of implementation of modern irrigation and water-saving technologies

Financial

- Deficient allocation of resources for proper maintenance and rehabilitation of irrigation water supply and distribution systems

- Inadequate collection of fees from consumers leading to poor financial management in water establishments

Administrative \& Institutional

- Lack of coordination between regulatory entities (ministries) and water establishments

- Lack of regulatory enforcement regarding water use and distribution

- Lack of political will in regulating and implementing well permits and payment of fines 


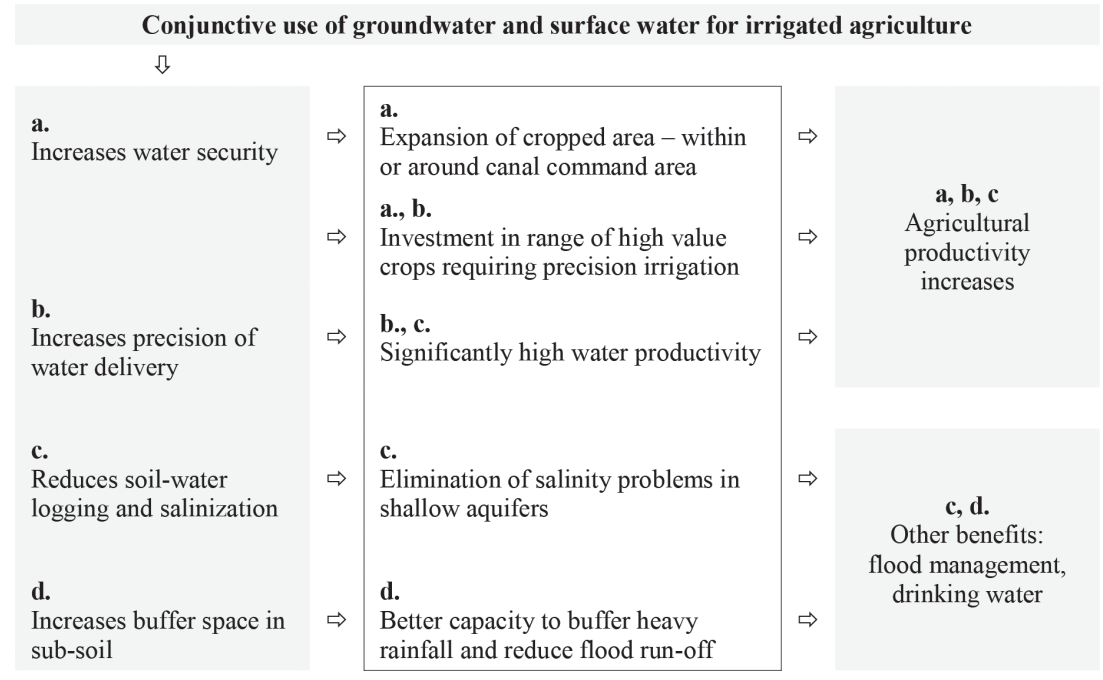

Figure 3: Benefits of conjunctive use for framework implementation.

Conjunctive use of groundwater and surface water (via canals) is critical at stages of crop/ plant growth, such as the shooting period for bananas. By increasing the precision of water delivery and reducing soil-water logging and salinization, water productivity is increased significantly and salinity problems in shallow aquifers are reduced, leading to an increase in agricultural productivity [42].

\section{CONCLUSION}

This study demonstrated through a farmers' field questionnaire $(\mathrm{n}=39)$ and reported groundwater quality that production yield of banana plantation along the Eastern Mediterranean in a low salinity group $\left(\mathrm{n}=21 ; \mathrm{EC}_{\mathrm{w}}<1 \mathrm{dS} / \mathrm{m}\right)$ was higher than in the high salinity group $(\mathrm{n}=18$; $\left.\mathrm{EC}_{\mathrm{w}}>1 \mathrm{dS} / \mathrm{m}\right)$ by nearly $25 \%\left(\sim 2.5 \mathrm{USD} / \mathrm{m}^{2} /\right.$ year $)$, representing the burden of salinity on farmers. Indirect adaptation measures practiced by the farmers encompassing fertigation via drip irrigation, leaching of salts and the conjunctive use of groundwater and surface water, minimized the impact on banana production yield at the encountered level of salinity. Current yields can be significantly affected if salinity levels continue to rise to the extent that the plantation of bananas can become economically non-viable forcing farmers to switch towards more salt-tolerant crops. Saltwater intrusion is expected to increase with climate change due to a projected decrease in precipitation and groundwater recharge, and an increase in water demand leading to further groundwater abstraction during the summer months in particular. The combination of adaptation strategies and methods of banana cultivation (multiple varieties, single and high-density planting techniques) suggest that production can be governed by agricultural and irrigation practices implemented by farmers. The cumulative effects of climate change, particularly decreased precipitation patterns, increase sea level rise and increase in water demand (high abstraction rates), are predicted to aggravate saltwater intrusion with related impacts justifying the adoption of early measures to protect groundwater exploitation. In this context, regulatory tools emphasizing tariff restructuring and well permitting are vital to ensure sustainability. 


\section{ACKNOWLEDGEMENTS}

The authors would like to acknowledge the support of the US Agency for International Development under the PEER initiative (Grant No. USAID-OAA-A-I1-00012) and the International Development Research Center (IDRC) of Canada (Grant No. 106706-001).

\section{REFERENCES}

[1] Stigter, T.Y., Nunes, J.P., Pisani, B., Fakir, Y., Hugman, R., Li, Y., Tomé, S., Ribeiro, L., Samper, J., Oliveira, R., Monteiro, J.P., Silva, A., Tavares, P.C.F., Shapouri, M., Cancela da Fonseca, L. \& El Himer,H., Comparative assessment of climate change and its impacts on three coastal aquifers in the Mediterranean. Regional Environmental Change, 14(1), pp. 41-56, 2014. https://doi.org/10.1007/s10113-012-0377-3

[2] De Montety, V., Radakovitch, O., Vallet-Coulomb, C., Blavoux, B., Hermitte, D., \& Valles, V., Origin of groundwater salinity and hydro-geochemical processes in a confined coastal aquifer: Case of the Rhône delta (Southern France). Applied Geochemistry, 23, pp. 2337-2349, 2008.

https://doi.org/10.1016/j.apgeochem.2008.03.011

[3] Masciopinto, C., Management of aquifer recharge in Lebanon by removing seawater intrusion from coastal aquifers. Journal of Environmental Management, 130, pp. 306-312, 2013.

https://doi.org/10.1016/j.jenvman.2013.08.021

[4] Blaylock, A.D., Soil salinity, salt tolerance, and growth potential of horticultural and landscape plants. University of Wyoming, College of Agriculture, Larmie, WY, 1994.

[5] Grattan, S.R., Irrigation water salinity and crop production. Farm Water Quality Planning, A Water Quality and Technical Assistance Program for California Agriculture (Publication 8066). University of California, 2002.

[6] Rahman, M.H., Lund, T. \& Bryceson, I. (2011). Salinity impacts on agro-biodiversity in three coastal, rural villages of Bangladesh. Ocean and Coastal Management, 54(6), pp. 455-468, 2011.

https://doi.org/10.1016/j.ocecoaman.2011.03.003

[7] Ondrasek, G., Rengel, Z. \& Veres, S., Soil salinization and salt stress in crop production. In Shanker, A. (Ed.). Abiotic stress in plants: Mechanisms and adaptations (pp. 171-191). InTech publishers, Croatia, 2010.

[8] Palacios, M. P., Haman, D.Z., Del-Nero, E., Pardo, A. \& Pavon, N., Banana production irrigated with treated effluent in the Canary Islands. American Society of Agricultural Engineers, 43(2), pp. 309-314, 2000. https://doi.org/10.13031/2013.2706

[9] Naifer, A., Al Rawahy, S.A. \& Zekri, S., Economic impact of salinity: The case of Al Batinah in Oman. International Journal of Agricultural Research, 6(2), pp. 134-142, 2011. https://doi.org/10.3923/ijar.2011.134.142

[10] Mokhtari, R., Economic impact of changes in water supply salinity. In Wilson, E. M. (Ed.). WRPMD'99: Preparing for the 21st Century, Proceedings of the 26th Annual Water Resources Planning and Management Conference, Tempe, Arizona, June 6-9, 1999. 
[11] El-Fadel M., Climate change and saltwater intrusion along the eastern Mediterranean: Socio-economic vulnerability and adaptation. International Development Research Center, Canada. American University of Beirut, 2015.

[12] Arvanitoyannis, I.S. \& Mavromati, A., Banana cultivars, cultivation practices, and physicochemical properties. Critical Reviews in Food Science and Nutrition, 49(2), pp. 113-135, 2009.

https://doi.org/10.1080/10408390701764344

[13] Storey, R. \& Walker, R., Citrus and salinity. Scientia Horticulturae, 78, pp. 39-81, 1999.

https://doi.org/10.1016/s0304-4238(98)00190-3

[14] Tanji, K. \& Kielen, N., Agricultural Drainage Water Management in Arid and SemiArid Areas. Food and Agricultural Organization of the UN Irrigation and Drainage Papers, 61, 2002

[15] Ayers, R.S., \& Westcot, D.W., Water quality for agriculture. Food and Agriculture Organization (FAO). FAO Irrigation and Drainage Paper 29, 1985.

[16] California Fertilizer Association., Western Fertilizer Handbook. Horticultural edition. Sacramento: Prentice-Hall. pp. 279, 1995.

[17] Litani River Authority, Qasimiya and Ras Al Ain Irrigation Project, 2014, available at: http://www.litani.gov.lb/en/?page_id=117. (accessed April 13 2017).

[18] Litani River Authority, Water tariffs in the three irrigation projects invested, 2014, available at: http://www.litani.gov.lb/wp/?page_id=1208. (accessed April 13 2017).

[19] Abou Masleh, F., Banana as replacement for citrus in Lebanese coasts. Al-Akhbar, (Issue 398), 2007, available at: http://www.al-akhbar.com/node/127740. (accessed April 13 2017).

[20] Khaled, S.M., Shfique, F.A. \& Hassan, M.B., Banana-growing tissue and its impact on the economic return per Fedden in Egypt. Nature and Science, 8(10), pp. 267-273, 2010.

[21] Ministry of Agriculture and Fisheries, Sultanate of Oman (MAF) / International Center for Biosaline Agriculture (ICBA), Oman salinity strategy. Agricultural status and salinity impact (Annex 2), 2012.

[22] De Langhe, E., Banana diversity in the Middle East (Jordan, Egypt, Oman). International Network for the Improvement of Banana and Plantain, (INIBAP), Montpellier, France, p. 52, 2002.

[23] International Council for Local Environmental Initiatives (ICLEI), The mitigationadaptation connection: Milestones, synergies and contradictions, 2014, available at: http://itepsrv1.itep.nau.edu/itep_course_downloads/ GeneralAQInfo/Climate\%20 Change/ICLEIMitigationAdaptationConnection.pdf. (accessed April 13 2017).

[24] Intergovernmental Panel on Climate Change (IPCC), Coastal systems and low-lying areas. In Climate Change 2014: Impacts, Adaptation, and Vulnerability. Part A: Global and Sectoral Aspects. Contribution of Working Group II to the Fifth Assessment IPCC Report. Field et al. (Eds.). Cambridge University Press, pp. 361-409, 2014.

[25] Rasmussen, P., Sonnenborg, T.O., Goncear, G. \& Hinsby, K., Assessing impacts of climate change, sea level rise, and drainage canals on saltwater intrusion to coastal aquifer. Hydrology and Earth Systems Sciences, 17, pp. 421-443, 2013.

https://doi.org/10.5194/hess-17-421-2013 
[26] Bhamidipati, S., Van der Lei, T. \& Herder, P., From mitigation to adaptation in asset management for climate change: A discussion. In Lee, W. B., et al. (Eds.). Proceedings of the 7th World Congress on Engineering Asset Management (WCEAM 2012), 2012.

[27] Sherif, M.M. \& Hamza, K.I., Mitigation of seawater intrusion by pumping brackish water. Transport in Porous Media, 43, pp. 29-44, 2001. https://doi.org/10.1023/a:1010601208708

[28] Ayers, R.S. \& Westcot, D.W., Water quality for agriculture. Food and Agriculture Organization (FAO). FAO Irrigation and Drainage Paper 29, 1985.

[29] Kashef, A.I. \& Csallany, C.S., Management and control of saltwater intrusion in coastal aquifers. Critical Reviews in Environmental Control, 7(3), pp. 217-275, 1977. https://doi.org/10.1080/10643387709381652

[30] Basri, M.H., Two new methods for optimal design of subsurface barrier to control seawater intrusion. PhD dissertation. University of Manitoba, Canada, 2001.

[31] Food and Agriculture Organization of the United Nations (FAO)., Land and water integration and river basin management. Proceedings of an FAO informal workshop, Rome, Italy, 31 January - 2 February 1993.

[32] Khomine, A., János, S. \& Balázs, K., Potential solutions in prevention of saltwater intrusion: A modelling approach. In Lambrakis, N., et al. (Eds.). Advances in the Research of Aquatic Environment 1. Springer. Berlin, Germany, 2011.

[33] Luyun Jr., Momii, K. \& Nakagawa, K., Effects of recharge wells and flow barriers on seawater intrusion. Groundwater, 49(2), pp. 239-249, 2011.

https://doi.org/10.1111/j.1745-6584.2010.00719.x

[34] El-Fadel, M., Zeinati, M. \& Jamali, D.,Water resources in Lebanon: Characterization, water balance and constraints. International Journal of Water Resources Development, 16(4), pp. 615-638, 2000. https://doi.org/10.1080/713672540

[35] Karaa, K., Karam, F. \& Raad, R., Moderization of irrigation systems: Measures to reduce pressure on water demand in Lebanon. In El Moujabber M., et al. (Eds.). Technological perspectives for rational use of water resources in the Mediterranean region. Bari: CIHEAM, pp. 241-254 (Série A. Séminaires Méditerranéens; n. 88), 2009.

[36] Institutional and Economic Instruments for Sustainable Water Management in the Mediterranean Basin (INECO), Institutional Framework and Decision Making Practices for Water Management in the Damour River Basin, Lebanon: Towards the development of a strategy for water stress mitigation. Coordination Action Project supported by the European Commission through the 6th Framework Programme (Contract No: INCOCT-2006-517673), 2009.

[37] Stephan, R.M., Legal framework of groundwater management in the Middle East (Israel, Jordan, Lebanon, Syria, and the Palestinian Territories). Water Resources in the Middle East, 2, pp. 293-299, 2007.

https://doi.org/10.1007/978-3-540-69509-7_30

[38] Hanson, B.R., May, D.E., Simünek, J., Hopmans, J.W. \& Hutmacher, R.B., Drip irrigation provides the salinity control needed for profitable irrigation of tomatoes in the San Joaquin Valley. California Agriculture, 63(3), pp. 131-136. https://doi.org/10.3733/ca.v063n03p131 
[39] Ahmed, B.A., Mohammed, A.A. \& Ihsan, M.I., Effect of drip irrigation system and fertigation on growth, yield and quality of banana cv. Grand Nain (Musa AAA). Research Application Summary. Second RU FORUM Biennial Meeting, 20-24 September 2010, Entebbe, Uganda, 2010.

[40] New South Wales Department of Primary Industries, Australia (NSW DPI), Horticultural fertigation: Techniques, equipment and management, 2000, available at: http://www.dpi. nsw.gov.au/land-and-water/water/irrigation/crops/fertigation. (accessed April 13 2017).

[41] Fipps, G., Irrigation water quality standards and salinity management strategies. Texas A\&M Agrilife Extension Service. B-1667 4-03, 2003, available at: http://soiltesting. tamu.edu/publications/B-1667.pdf. (accessed April 13, 2017).

[42] Foster, S., van Steenbergen, F., Zuleta, J. \& Garduño, H., Conjunctive use of groundwater and surface water: From spontaneous coping strategy to adaptive resource management. GW-MATE Strategic Overview Series 2, World Bank, Washington DC, 2010. 